\title{
Pengaruh Model Pembelajaran Student Team Achievement Division Berbantuan Media Power of Vision Terhadap Hasil Belajar IPA Materi Sistem Pernapasan Manusia
}

\author{
Lisnawati Safitri ${ }^{*}$, Jovialine A. Rungkat ${ }^{2}$ \\ 1,2 Jurusan Pendidikan IPA, FMIPA, Universitas Negeri Manado \\ *e-mail: lisnawatisafitri14@gmail.com
}

\begin{abstract}
Abstrak. Proses pembelajaran IPA saat ini masih terfokus pada guru, dimana belum menggunakan model pembelajaran yang membuat siswa aktif dan media pembelajaran yang menarik sehingga siswa merasa bosan ketika belajar dan berpengaruh terhadap hasil belajar. Penelitian ini bertujuan untuk mengetahui pengaruh model pembelajaran Student Team Achievement Division (STAD) berbantuan media Power of Vision (PV) terhadap hasil belajar IPA materi sistem pernapasan manusia, dengan menggunakan metode quasi experimental design dan desain penelitian nonequivalent control group design. Populasi dalam penelitian ini adalah seluruh siswa kelas VIII yang terdiri dari 3 kelas. Pengambilan sampel dilakukan dengan teknik random sampling dan terambil 2 kelas dengan jumlah masing-masing 20 siswa, kelas VIIIA sebagai kelas kontrol dan kelas VIIIB sebagai kelas eksperimen. Pengambilan data dilakukan dengan memberikan pretest sebelum proses pembelajaran dilaksanakan dan posttest setelah proses pembelajaran dilaksanakan. Hasil penelitian diperoleh berupa nilai rata-rata hasil posttest kelas eksperimen adalah 87 sedangkan untuk kelas kontrol nilai rata-rata hasil posttest adalah 76. Setelah di uji hipotesis (uji-t) diperoleh hasil thitung $=4,60>$ $t_{\text {tabel }}=1,685$ maka $\mathrm{H}_{0}$ ditolak dan $\mathrm{H}_{\mathrm{a}}$ diterima. Sehingga dapat disimpulkan bahwa rata-rata hasil belajar siswa yang mengikuti pembelajaran dengan model STAD berbantuan media PV lebih tinggi dibandingkan dengan rata-rata hasil belajar siswa yang menggunakan model pembelajaran konvensional.
\end{abstract}

Kata kunci: student team achievement division, media power of vision, hasil belajar

\begin{abstract}
The science learning process is currently still focused on teachers, who have not used learning models that make students active and learning media that make students feel bored when studying and affect learning outcomes. This study aims to determine the effect of the Student Team Achievement Division (STAD) learning model assisted by the Power of Vision (PV) media on the learning outcomes of the human respiratory system science material, using a quasi-experimental design method and a nonequivalent control group design research design. The population in this study were all students of class VIII which consisted of 3 classes. Sampling was done by random sampling technique and taken 2 classes with a total of 20 students each, class VIIIA as the control class and class VIIIB as the experimental class. Data collection was carried out by giving a pretest before the learning process was carried out and a posttest after the learning process was carried out. The results obtained in the form of the average value of the posttest results of the experimental class is 87 while for the control class the average value of the posttest results is 76. After testing the hypothesis ( $t$-test) the results obtained $t_{\text {count }}=4.60>t_{\text {table }}=1.685$ then $H_{0}$ is rejected and $H_{a}$ accepted. So it can be concluded that the average learning outcomes of students who take part in learning with the STAD model assisted by PV media are higher than the average learning outcomes of students who use conventional learning models.
\end{abstract}

Keywords: student team achievement division, power of vision media, learning outcomes 


\section{PENDAHULUAN}

Pendidikan merupakan suatu proses perubahan sikap dan perilaku seseorang dalam upaya mendewasakan manusia melalui proses pembelajaran. Proses pendidikan juga mengarah pada pembentukan sikap, pengembangan intelektual, dan pengembangan keterampilan peserta didik sehingga arah dan tujuan dapat tercapai. Karena tujuan pendidikan pada dasarnya adalah untuk mengantarkan peserta didik menuju perubahan-perubahan tingkah laku, baik berupa pengetahuan, sikap, moral, maupun sosial agar dapat hidup mandiri sebagai makhluk individu dan hidup bermasyarakat dengan baik sebagai makhluk sosial (Chasanah, Sinon \& Widyaningsih, 2016). Selain itu, pendidikan memegang peranan yang sangat penting dalam proses peningkatan kualitas sumber saya manusia. Dalam proses pendidikan tersebut, berbagai faktor-faktor yang dapat meningkatkan prestasi akademik siswa harus diperhatikan dengan baik (Laa, Winata \& Meilani, 2017).

Proses pembelajaran IPA menekankan pada pemberian pengalaman langsung untuk mengembangkan kompetensi yang diarahkan untuk membantu siswa memperoleh pemahaman yang lebih mendalam tentang alam (Saadah \& Susanti, 2020).

Hasil observasi yang peneliti lakukan di SMP Negeri 2 Dumoga pada bulan Maret tahun 2020 diketahui bahwa dalam proses pembelajaran guru belum menggunakan model pembelajaran yang membuat siswa aktif dan dalam proses belajar mengajar siswa hanya sebagai penerima materi. Selain itu, guru belum menggunakan media pembelajaran yang menarik yang sesuai dengan kebutuhan materi dan karakteristik siswa dan hanya fokus pada buku cetak ketika mengajar. Hal ini menyebabkan siswa merasa bosan ketika belajar IPA dan mengakibatkan hasil belajar IPA belum maksimal, dilihat dari hasil belajar yang ditunjukkan guru terdapat $65 \%$ nilai siswa berkisar antara 60-70 dan belum mencapai nilai KKM yang ditentukan sekolah yakni 75 . Jadi, masalah utama dalam penelitian ini adalah bagaimana meningkatkan hasil belajar siswa dengan menggunakan model pembelajaran dan media pembelajaran yang menarik minat siswa sehingga mereka semangat kembali untuk belajar. Untuk mengatasi permasalahan tersebut, perlu adanya model pembelajaran yang dapat membangkitkan semangat siswa dalam belajar IPA dan juga media pembelajaran yang menarik yang dapat diintegrasikan dengan media sosial. Disini peneliti memilih model pembelajaran Student Team Achievement Division (STAD).

Model pembelajaran STAD merupakan model pembelajaran yang cukup sederhana dimana siswa dilatih menjalin kerjasama dalam satu kelompok kecil dan saling membantu dalam memecahkan masalah serta dapat diimplementasikan dalam pembelajaran untuk meningkatkan hasil belajar siswa (Daga \& Yoksiana, 2020). Jika siswa ingin kelompoknya mendapat hadiah maka mereka harus membantu teman kelompoknya ketika mempelajari pelajaran. Siswa diberi kesempatan bekerja sama setelah guru selesai memberikan pelajaran, tetapi ketika mengerjakan kuis siswa tidak diperkenankan untuk saling membantu, sehingga setiap siswa diharuskan untuk mampu menguasai materi yang diberikan (Fatdha \& Alamsyah, 2020).

Peranan media pembelajaran dalam proses pembelajaran merupakan satu kesatuan yang tidak dapat dipisahkan dari dunia pendidikan. Media pembelajaran merupakan segala sesuatu yang dapat digunakan untuk menyalurkan pesan pengirim kepada penerima, sehingga dapat merangsang pikiran, perasaan, perhatian, dan minat peserta didik untuk belajar (Tafonao, 2018). Pemilihan media juga harus disesuaikan dengan kebutuhan materi siswa saat ini yang dimana sangat bergantung dengan teknologi dan kurang tertarik dengan buku-buku. Sekarang ini siswa lebih sering bermain game online, bersosial media atau bahkan banyak siswa yang sudah sering melihat videovideo pembelajaran di Youtube. Oleh 
karena itu, peneliti menggunakan media Power of Vision (PV) yang merupakan media audio visual berupa slide bersuara dan memanfaatkan media sosial Youtube dan materi yang cocok untuk diangkat adalah materi sistem pernapasan manusia karena materi terebut berisi gambar-gambar tentang organ-organ dalam pada manusia yang tidak dapat dilihat secara langsung oleh siswa.

Oleh karena itu, penelitian ini bertujuan untuk mengetahui pengaruh model pembelajaran STAD berbantuan media PV terhadap hasil belajar IPA materi sistem pernapasan manusia.

\section{METODE PENELITIAN}

Penelitian ini dilaksanakan di SMP Negeri 2 Dumoga pada semester genap tanggal 18 januari - 08 februari tahun ajaran 2020/2021. Populasi dalam penelitian ini adalah seluruh siswa kelas VIII yang terdiri dari 3 kelas yaitu kelas VIII A, VIII B, dan VIII C dan sampel dari penelitian ini diambil secara acak yaitu kelas VIII A sebagai kelas kontrol dengan jumlah siswa 20 orang dan kelas VIII B sebagai kelas eksperimen dengan jumlah siswa 20 orang.

Penelitian ini merupakan jenis penelitian eksperimen dengan pendekatan kuantitatif. Penelitian ini menggunakan metode quasi experimental design dengan menggunakan rancangan nonequivalent control group design yang dapat dilihat pada Tabel 1.

Tabel 1. Rancangan nonequivalent control group design

\begin{tabular}{llll}
\hline Group & Pretest & Perlakuan & Posttest \\
\hline Eksperimen & $\mathrm{O}_{1}$ & $\mathrm{X}$ & $\mathrm{O}_{2}$ \\
Kontrol & $\mathrm{O}_{3}$ & - & $\mathrm{O}_{4}$ \\
\hline \multicolumn{4}{c}{ (Sugiyono, 2016) }
\end{tabular}

Berdasarkan Tabel 1, dapat dilihat bahwa penelitian ini dibagi menjadi dua kelompok, yaitu kelompok kelas eksperimen dan kelompok kelas kontrol, dimana kelas eksperimen diberikan perlakuan sedangkan kontrol tidak. Kedua kelas sama-sama diberikan pretest dan posttest.
Instrumen dalam penelitian ini adalah seperangkat soal dalam bentuk pilihan ganda yang terdiri dari soal pretest dan posttest. Pretest adalah tes awal yang diberikan untuk mengukur pemahaman awal siswa sebelum diberikan perlakuan, sedangkan posttest adalah tes akhir yang bertujuan untuk mengetahui pemahaman akhir siswa setelah diberikan perlakuan. Pengujian butir soal menggunakan uji validitas dan uji reliabilitas.

Pengujian validitas dalam penelitian ini menggunakan hitungan koefisien korelasi pearson product moment, pengujian reliabilitas menggunakan rumus KR-20 (Sugiyono, 2016).

Teknik analisis data yang digunakan yaitu uji normalitas yang menggunakan uji Liliefors untuk mengetahui apakah data berdistribusi normal, kemudian uji homogenitas untuk mengetahui kesamaan kedua varians menggunakan persamaan uji-F. Setelah uji prasyarat terpenuhi, dimana jika data kelas kontrol dan kelas eksperimen berdistribusi normal dan homogen maka pengujian hipotesis dapat dilanjutkan yaitu dengan menggunakan pengujian hipotesis menggunakan rumus uji $t$ dengan taraf signifikan $\alpha=0,05$ (Sugiyono, 2016).

Uji hipotesis berguna untuk mengetahui apakah ada pengaruh signifikan pada model pembelajaran STAD berbantuan media PV terhadap hasil belajar siswa pada materi IPA. Sehingga hipotesis dalam penelitian ini yaitu terdapat pengaruh model pembelajaran STAD berbantuan media PV terhadap hasil belajar IPA materi sistem pernapasan manusia.

\section{HASIL DAN PEMBAHASAN Hasil Penelitian}

Hasil pengumpulan data pretest dan posttest di kelas ekperimen dapat dilihat pada Tabel 2.

Tabel 2. Ringkasan data hasil pretest posttest kelas eksperimen

\begin{tabular}{llll}
\hline & Pretest & Posttest & Selisih \\
\hline Jumlah & 750 & 1740 & 990 \\
Nilai max & 50 & 100 & 55 \\
Nilai min & 30 & 75 & 40
\end{tabular}




\begin{tabular}{llll}
\hline & Pretest & Posttest & Selisih \\
\hline Nilai rata-rata & 37,5 & 87 & 49,5 \\
S. deviasi & 5,96 & 7,5 & 4,5 \\
Varians & 35,52 & 56,31 & 20,78 \\
\hline
\end{tabular}

Berdasarkan Tabel 2, dapat dilihat nilai rata-rata pretest kelas eksperimen diperoleh 37,5 dan nilai posttest diperoleh 87 dan selisih sebesar 49,5.

Hasil pengumpulan data pretest dan posttest di kelas kontrol dapat dilihat pada Tabel 3.

Tabel 3. Ringkasan data hasil pretest posttest kelas kontrol

\begin{tabular}{llll}
\hline & Pretest & Posttest & Selisih \\
\hline Jumlah & 675 & 1520 & 845 \\
Nilai max & 45 & 80 & 50 \\
Nilai min & 25 & 65 & 35 \\
Nilai rata-rata & 33,75 & 76 & 42,25 \\
S. deviasi & 6,04 & 3,47 & 5,25 \\
Varians & 36,51 & 12,10 & 27,56 \\
\hline
\end{tabular}

Berdasarkan Tabel 3, dapat dilihat nilai rata-rata pretest kelas eksperimen diperoleh 33,75 dan nilai posttest diperoleh 76 dan selisih sebesar 42,25.

Pengujian data menggunakan uji Liliefors melalui software Microsoft Excel 2016 pada hasil pretest dari masingmasing kelas, baik kelas eksperimen maupun kelas kontrol diperoleh data pada kedua kelas berdistribusi normal. Pengujian homogenitas data pretest siswa dalam penelitian ini menggunakan uji $\mathrm{F}$, melalui software Microsoft Excel 2016, diperoleh data dari kedua kelas homogen.

Setelah uji prasyarat terpenuhi, dimana data kelas kontrol dan kelas eksperimen berdistribusi normal dan homogen maka pengujian hipotesis dapat dilanjutkan yaitu dengan menggunakan uji t. Ringkasan pengujian hipotesis dapat dilihat pada Tabel 4.

Tabel 4. Ringkasan pengujian hipotesis

\begin{tabular}{cccl}
\hline$t_{\text {hitung }}$ & t tabel & Kriteria & Kesimpulan \\
\hline 4,60 & 1,685 & thitung $>$ t $_{\text {tabel }}$ & $\begin{array}{l}\text { Tolak } \mathrm{H}_{0} \text { dan } \\
\text { terima } \mathrm{H}_{\mathrm{a}}\end{array}$ \\
\hline
\end{tabular}

Berdasarkan Tabel 4, diperoleh thitung sebesar 4,60 dan tabel sebesar 1,685 sehingga sesuai kriteria yang ada diperoleh kesimpulan bahwa tolak $\mathrm{H}_{0}$ dan terima $\mathrm{H}_{\mathrm{a}}$.

\section{Pembahasan}

Penelitian ini telah dilaksanakan di SMP Negeri 2 Dumoga. Namun, sebelum melakukan penelitian pada kelas eksperimen dan kelas kontrol, peneliti pertama kali melakukan pengujian instrumen penelitian di kelas IX A SMP Negeri 2 Dumoga yang sebelumnya sudah pernah menerima materi sistem pernapasan manusia. Selanjutnya, peneliti melakukan penelitian di kelas VIII A sebagai kelas kontrol dan kelas VIII B sebagai kelas eksperimen. Berdasarkan penelitian yang telah dilakukan, diperoleh hasil thitung $=4,60$ dan $\mathrm{t}_{\text {tabel }}=1,685$ maka tolak $\mathrm{H}_{0}$ yang menyatakan hasil belajar IPA dengan menggunakan model pembelajaran STAD berbantuan media PV lebih kecil atau sama dengan hasil belajar IPA dengan menggunakan model pembelajaran konvensional dan terima $\mathrm{H}_{\mathrm{a}}$ yang menyatakan hasil belajar IPA dengan menggunakan model pembelajaran STAD berbantuan media PV lebih tinggi dari hasil belajar IPA dengan menggunakan model pembelajaran konvensional.

Langkah pertama penelitian ini dimulai dengan dilakukannya uji validitas dan reliabilitas soal dalam bentuk objektif. Kemudian memberikan tes awal (pretest) pada kedua kelas yang telah ditentukan yaitu kelas eksperimen dan kelas kontrol. Hasil pretest pada kelas eksperimen memiliki nilai lebih tinggi dibandingkan nilai pada kelas kontrol. Setelah melakukan pretest, langkah selanjutnya adalah dilakukan proses belajar mengajar pada kedua kelas dengan menggunakan model pembelajaran yang berbeda, dimana pada kelas eksperimen menggunakan model pembelajaran STAD berbantuan media PV sedangkan pembelajaran pada kelas kontrol menggunakan model konvensional. Setelah materi yang diajarkan selesai, maka langkah berikutnya memberikan tes akhir (posttest) yang bertujuan untuk melihat apakah ada pengaruh dari model dan 
media yang digunakan sehingga dapat membuat hasil belajar IPA meningkat.

$$
\text { Pembelajaran pada kelas }
$$

eksperimen menggunakan model pembelajaran STAD berbantuan media PV dimana siswa dibagi dalam kelompok heterogen dan dibagi sesuai dengan kemampuan akademik yang berbeda dengan varian jenis kelamin. Sebelum memulai diskusi, siswa diminta untuk menyaksikan sebuah video materi pelajaran yang telah disiapkan. Gambaran tentang media PV dapat dilihat pada Gambar 1.

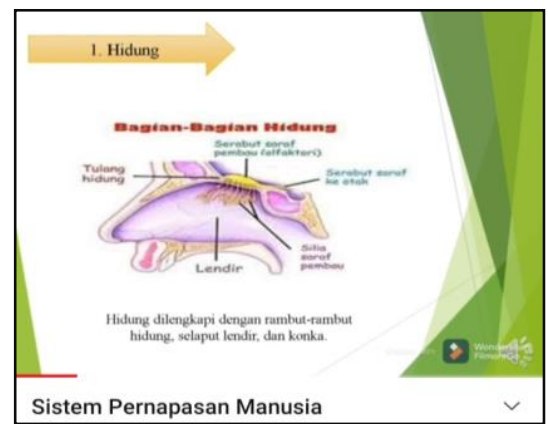

Gambar 1. Contoh media PV

Berdasarkan Gambar 1, dapat dilihat bahwa siswa dapat melihat dan mendengar materi yang ada di media PV yang mana median tersebut berbentuk audio visual yang dapat diakses melalui Youtube.

Setelah siswa selesai melihat dan mendengar materi yang ada di media PV, peneliti membagikan LKS untuk siswa diskusikan dengan teman kelompok masing-masing kemudian siswa mempresentasikannya. Setelah proses diskusi selesai, guru memberikan kuis kepada siswa untuk melihat kemampuan siswa dan memberikan penghargaan kepada siswa yang aktif serta mendapat nilai kuis paling tinggi. Selama proses pembelajaran berlangsung, peneliti selalu mendampingi siswa dan memberikan bimbingan pada kelompok yang masih kesulitan. Selain itu, siswa juga terlibat langsung serta saling memberikan umpan balik selama proses belajar mengajar.

Melalui model pembelajaran STAD berbantuan media PV dalam proses pembelajaran IPA materi sistem pernapasan manusia, siswa mampu mengembangkan kemampuan bekerja sama dan tidak lagi pasif selama proses belajar mengajar dikarenakan siswa mampu memecahkan masalah saat proses tanya jawab dalam diskusi kelompok. Contohnya ketika siswa mengerjakan LKS ditambah dengan adanya media PV, siswa lebih termotivasi dalam belajar dan membuat hasil belajar meningkat. Hal tersebut dikarenakan media PV merupakan media yang tidak hanya berisi gambar namun juga berisi suara seperti audio visual. Hal ini selaras dengan apa yang diungkapkan oleh Edgar Dale (dalam Ulfayana, 2018) melalui kerucut pengalaman bahwa hasil belajar seseorang diperoleh melalui pengalaman langsung (kongkrit), kenyataan yang ada di lingkungan kehidupan seseorang kemudian melalui benda tiruan, sampai kepada lambang verbal (abstrak). Edgar Dale meyakini bahwa proses dan hasil belajar dipengaruhi oleh cara belajar mereka seperti yang ditunjukkan pada Gambar 2.

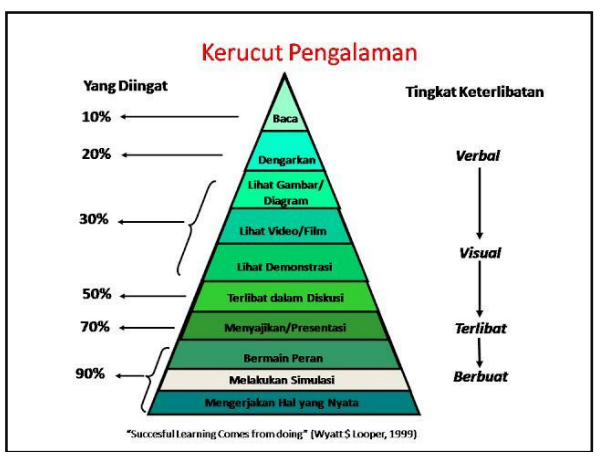

Gambar 2. Kerucut pengalaman Edgar Dale

Berdasarkan Gambar 2, dapat dilihat bahwa jika siswa belajar pada apa yang dibaca maka pengaruhnya terhadap ingatan hanya sebedar 10\%. Jika siswa belajar pada apa yang didengarnya maka ingatannya akan meningkat menjadi $20 \%$. Jika individu belajar pada apa yang dilihat, seperti melihat gambar atau video, cara itu mempengaruhi kemampuan mengingat menjadi $30 \%$. Jika apa yang dilihatnya disertai suara yang dapat didengar maka akan meningkat menjadi 50\%. Jika yang dipelajari itu diucapkan dan ditulis maka akan mempengaruhi peningkatan ingatan hingga $70 \%$. Sedangkan jika apa yang 
dipelajari itu dipraktekkan atau dilakukan maka ingatan akan naik 90\% (Ulfayana, 2018).

Kehadiran media juga mempunyai arti yang cukup penting dalam pembelajaran, karena dalam proses belajar tersebut ketidakjelasan materi pelajaran dapat di bantu dengan menghadirkan sebuah media sebagai perantara. Hal ini sejalan dengan apa yang diungkapkan oleh Nurrita (2018), bahwa media pembelajaran adalah alat yang dapat membantu proses belajar mengajar sehingga makna pesan yang disampaikan menjadi lebih jelas dan tujuan pendidikan atau pembelajaran dapat tercapai dengan efektif dan efisien.

Oleh karena itu, dalam proses pembelajaran berlangsung, guru diharapkan mampu berinovasi dalam menerapkan proses pembelajaran yang efektif, efisien, menyenangkan dan mampu memotivasi siswa (Paat, Kawuwung, \& Mokalu, 2021).

Pembelajaran pada kelas kontrol dilakukan dengan menggunakan model pembelajaran konvensional. Dimana ketika kegiatan belajar mengajar berlangsung, guru yang berperan sebagai pemberi materi dan siswa sebagai penerima materi sehingga siswa kurang termotivasi untuk belajar dan berpengaruh terhadap hasil belajar IPA.

Berdasarkan hasil penelitian, dinyatakan bahwa pembelajaran dengan menggunakan model STAD berbantuan media PV berpengaruh terhadap hasil belajar IPA.

\section{KESIMPULAN}

Berdasarkan hasil penelitian dan pembahasan, diperoleh bahwa rata-rata hasil belajar IPA yang diajarkan menggunakan model pembelajaran Student Team Achievement Division (STAD) berbantuan media Power of Vision (PV) lebih tinggi dari rata-rata hasil belajar IPA yang diajarkan menggunakan model konvensional. Sehingga dapat disimpulkan bahwa model pembelajaran STAD berbantuan media PV berpengaruh terhadap hasil belajar IPA.

\section{DAFTAR PUSTAKA}

Chasanah, U. U., Sinon, I. L., \& Widyaningsih, S. W. (2016). Penerapan model kooperatif tipe STAD (Student Team Achivement Divisions) dengan media peta konsep untuk meningkatkan hasil belajar IPA peserta didik kelas IX A SMP Negeri 19 Manokwari. Pancaran Pendidikan, 5(2), 25-38.

Daga, A. T. \& Yoksiana. (2020). Pengaruh Penerapan model pembelajaran Student Team Achievement Divisions (STAD) terhadap hasil belajar IPA siswa kelas VIII SMP Aloysius Bandung. VEKTOR: Jurnal Pendidikan IPA, 1(1), 7-18.

Fatdha, S. E., \& Alamsyah, M. (2020). Penerapan metode Student Teams Achievement Division (STAD) dalam media pembelajaran multimedia kreatif. Jurnal Teknologi Dan Open Source, 3(2), 284-297.

Laa, N., Winata, H., \& Meilani, R. I. (2017). Pengaruh model pembelajaran kooperatif tipe student teams achievement division terhadap minat belajar siswa. Jurnal Pendidikan Manajemen Perkantoran (JPManper), 2(2), 251-260.

Nurrita, T. (2018). Pengembangan media pembelajaran untuk meningkatkan hasil belajar siswa. MISYKAT: Jurnal Ilmu-ilmu Al-Quran, Hadist, Syari'ah dan Tarbiyah, 3(1), 171-210.

Paat, M., Kawuwung, F. R., \& Mokalu, Y. B. (2021). Penerapan LKS model pembelajaran berbasis masalah untuk meningkatkan kemampuan berpikir tingkat tinggi SMPN 5 Tondano. JISIP (Jurnal Ilmu Sosial dan Pendidikan), 5(2), 469-476.

Saadah, F. Y., \& Susanti, L. Y. (2020). Pengaruh model pembelajaran kooperatif tipe STAD terhadap hasil belajar ipa kelas VII MTs. Indonesian Journal of Mathematics and Natural Science Education, 1(2), 81-90.

Sugiyono. (2016). Metode penelitian pendidikan. Bandung: Alfabeta.

Tafonao, T. (2018). Peranan media pembelajaran dalam meningkatkan minat belajar mahasiswa. Jurnal Komunikasi Pendidikan, 2(2), 103-114. 
Ulfayana, U. (2018). Efektivitas Penggunaan media berdasarkan teori belajar Edgar Dale terhadap peningkatan hasil belajar fikih di MTs Negeri 2 Bulukumba. Skripsi. Universitas Islam Negeri Alauddin Makassar. 